\title{
Chrysin abrogates cisplatin-induced oxidative stress, p53 expression, goblet cell disintegration and apoptotic responses in the jejunum of Wistar rats
}

\author{
Rehan Khan, Abdul Quaiyoom Khan, Wajhul Qamar, Abdul Lateef, Farrah Ali, \\ Muneeb U. Rehman, Mir Tahir, Swati Sharma and Sarwat Sultana* \\ Section of Molecular Carcinogenesis and Chemoprevention, Department of Medical Elementology and Toxicology, \\ Faculty of Science, Jamia Hamdard (Hamdard University), Hamdard Nagar, New Delhi 110062, India
}

(Submitted 7 September 2011 - Final revision received 9 November 2011 - Accepted 10 November 2011 - First published online 6 February 2012)

\begin{abstract}
Cisplatin (cis-diamminedichloroplatinum (II) (CDDP)) is a commonly used chemotherapeutic drug for the treatment of numerous forms of cancer, but it has pronounced adverse effects, namely nephrotoxicity, ototoxicity, neurotoxicity, hepatotoxicity, diarrhoea and nausea. CDDP-induced emesis and diarrhoea are also marked toxicities that may be due to intestinal injury. Chrysin (5,7-dihydroxyflavone), a natural flavone commonly found in many plants, possesses multiple biological activities, such as antioxidant and anti-inflammatory properties. In the present study, we investigated the protective effect of chrysin against CDDP-induced jejunal toxicity. The plausible mechanism of CDDP-induced jejunal toxicity includes oxidative stress, p53 and apoptosis via up-regulating the expression of caspase-6 and - 3 . Chrysin was administered to Wistar rats orally in maize oil. A single intraperitoneal injection of CDDP was given and the animals were killed after $24 \mathrm{~h}$ of CDDP injection. Chrysin ameliorated CDDP-induced lipid peroxidation, increase in xanthine oxidase activity, glutathione depletion, decrease in antioxidant (catalase, glutathione reductase, glutathione peroxidase and glucose-6-phosphate dehydrogenase) and phase-II detoxifying (glutathione- $S$-transferase and quinone reductase) enzyme activities. Chrysin attenuated CDDP-induced goblet cell disintegration, enhanced expression of $\mathrm{p} 53$ and apoptotic tissue damage. Histological findings further substantiated the protective effects of chrysin against CDDP-induced damage in the jejunum. The results of the present study demonstrate that oxidative stress and apoptosis are closely associated with CDDP-induced toxicity and chrysin shows the protective efficacy against CDDP-induced jejunum toxicity possibly via attenuating the oxidative stress and apoptotic tissue damage.
\end{abstract}

Key words: Cisplatin: Jejunum toxicity: Oxidative stress: p53: Caspases: Goblet cells

Cisplatin (cis-diamminedichloroplatinum (II) (CDDP); Fig. 1) is a commonly used chemotherapeutic drug for the treatment of various forms of cancer ${ }^{(1-3)}$. The chemotherapeutic efficacy of CDDP is increased by increasing the dose, but it is usually accompanied by severe adverse effects including nephrotoxicity, ototoxicity, neurotoxicity, hepatotoxicity, nausea and emesis, with $67 \%$ of patients experiencing diarrhoea ${ }^{(4-8)}$. The cytotoxic effects of anti-neoplastic drugs are not specific in action against tumour cells but also damage normal rapidly proliferating cells, namely intestinal epithelial cells ${ }^{(9)}$. The exact mechanism of CDDP toxicity is not fully understood, but the plausible mechanism may involve oxidative stress ${ }^{(10)}$ which is due to the devastating production of reactive oxygen species (ROS), e.g. the superoxide anion $\left(\mathrm{O}_{2}^{-}\right), \mathrm{H}_{2} \mathrm{O}_{2}$, hydroxyl radical
$(\mathrm{OH})$, etc. by $\mathrm{CDDP}^{(11)}$, and consequently these ROS may further interact with DNA, lipids and proteins ${ }^{(12)}$. CDDP can act on the sulphydryl ( $-\mathrm{SH}$ ) groups of cellular proteins ${ }^{(13)}$, but DNA is the main cellular target of CDDP that may lead to DNA damage induced by ROS and platinum-DNA (Pt-DNA) adduct formation, thus hampering the cell division or DNA synthesis and its repair mechanism which leads to apoptotic cell death $^{(14,15)}$

Increasing amounts of evidence suggest that the natural compounds with antioxidant properties subside CDDP toxicity $^{(16-20)}$. Therefore, chemotherapy treatment with compounds having antioxidant properties may augment the efficiency of antineoplastic drugs and also may decrease the systemic toxicity induced by chemotherapy ${ }^{(21)}$. There is

\footnotetext{
Abbreviations: b.wt., body weight; CAT, catalase; CDDP, cisplatin; G6PD, glucose-6-phosphate dehydrogenase; GPx, glutathione peroxidase; GR, glutathione reductase; GSH, reduced glutathione; GST, glutathione-S-transferase; LPO, lipid peroxidation; MDA, malondialdehyde; PMS, post-mitochondrial supernatant; $\mathrm{QR}$, quinone reductase; ROS, reactive oxygen species; SOD, superoxide dismutase; TBS, Tris-buffered saline; XO, xanthine oxidase.
} 


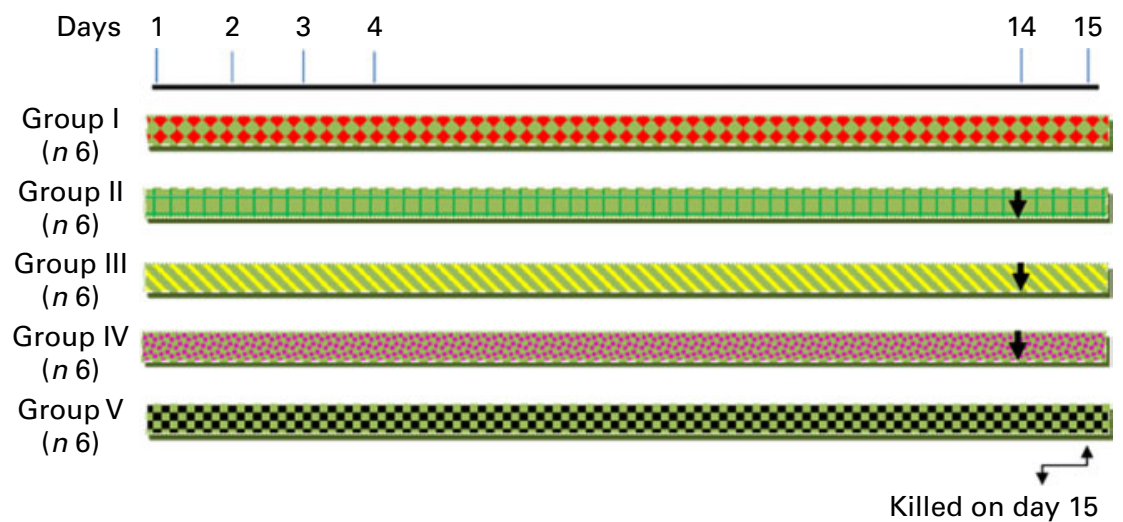

Fig. 1. Schematic representation of the experimental design. 14) arrow indicates cisplatin injection; $匹$, chrysin $(25 \mathrm{mg} / \mathrm{kg}$ b.wt. orally every day for $14 \mathrm{~d})+$ cisplatin $(7.5 \mathrm{mg} / \mathrm{kg}$ b.wt. IP once at day 14$)$ arrow indicates cisplatin injection; $\mathbf{\square}$, chrysin $(50 \mathrm{mg} / \mathrm{kg}$ b.wt. orally every day for $14 \mathrm{~d})+$ cisplatin $(7.5 \mathrm{mg} / \mathrm{kg}$ b.wt. IP once at day 14$)$ arrow indicates cisplatin injection; $\mathbf{\Sigma}$, chrysin only ( $50 \mathrm{mg} / \mathrm{kg}$ b.wt., orally every day for $14 \mathrm{~d}$ ) (a colour version of this figure can be found online at journals.cambridge.org/bjn).

also no report or finding to date that antioxidants impede conventional cancer therapeutics in vivo; moreover, antioxidants and chemotherapy may augment the efficacy of the treatment ${ }^{(11)}$. Thus, there is a need to explore the natural compound that can effectively diminish the CDDP-induced toxicity to improve its chemotherapeutic efficacy via decreasing the chemoresistance and increasing the chemosensitisation of CDDP. Flavonoids are naturally occurring polyphenols that possess various pharmacological properties and therapeutic applications. This is attributed possibly due to the phenolic structures which have antioxidant and free-radical-scavenging properties $^{(22)}$.

Chrysin (5,7-dihydroxyflavone; Fig. 2) belongs to this category which is found in high amounts in honey and bee propolis and is also present in various plants ${ }^{(23)}$. It has antioxidant, anti-inflammatory, antiviral and anti-cancer properties ${ }^{(23)}$. Chrysin has very low oral bioavailability and after recommended oral doses of $400 \mathrm{mg}$, there were only trace amounts present in plasma, equivalent to an approximate bioavailability of $0.003-$ $0.02 \%^{(24-26)}$. Chrysin enhances the level of testosterone by inhibiting the aromatase enzyme which converts testosterone into oestradiol and is already available on the market as a dietary supplement in the form of capsules $(500 \mathrm{mg} /$ capsule; iHerb, Inc. and VitaDigest), with six capsules/d as the highest suggested dose ${ }^{(23)}$. The potential side effect of chrysin has not been well studied, but it has cytotoxic effects on normal trout liver cells ${ }^{(27)}$. These insights into chrysin may help in reducing the CDDP toxicity which may lead to improving the chemotherapeutic efficacy of CDDP.

Based on this information, the present study was intended to explore the anticipatory effects of chrysin against CDDPinduced jejunal toxicity. The aim of this study was hence to examine the prophylactic effects of chrysin against CDDP-induced oxidative stress, p53 expression, goblet cell disintegration and apoptotic responses in the jejunum of Wistar rats.

\section{Experimental methods}

\section{Chemicals}

Reduced glutathione (GSH), oxidised glutathione, NADPH, NADP +, FAD, EDTA, thiobarbituric acid, pyrogallol, poly-L-lysine, xanthine, glucose-6-phosphate, bovine serum albumin, Mayer's haematoxylin, dichlorophenolindophenol, 5,5'-dithio-bis-(2-nitrobenzoic acid), chrysin, 1-chloro-2,4-dinitrobenzene and glutathione reductase (GR) were obtained from Sigma (Sigma Chemical Company). CDDP was purchased from Dr Reddy's. $\mathrm{H}_{2} \mathrm{O}_{2}$, magnesium chloride, sulphosalicylic acid, perchloric acid, TCA, Tween-20, FolinCiocalteau reagent, sodium potassium tartarate, di-sodium hydrogen phosphate, sodium di-hydrogen phosphate and sodium hydroxide were purchased from E. Merck Limited. All other chemicals and reagents were of the highest-purity grade commercially available.

\section{Animals}

For the experimental study, 4- to 6-week-old male albino rats $(120-150 \mathrm{~g})$ of the Wistar strain were obtained from the Central Animal House of Hamdard University, New Delhi, India. All procedures for using experimental animals were checked and permitted by the 'Institutional Animal Ethical Committee' that is fully accredited by the Committee for Purpose of Control and Supervision on Experiments on Animals Chennai, India. Approval ID/project number for this study is 740 . The animals were housed in polypropylene cages in groups of four rats per cage and were kept in a room maintained at $25 \pm 2^{\circ} \mathrm{C}$ with a $12 \mathrm{~h}$ light $-12 \mathrm{~h}$ dark cycle. They were allowed to acclimatise for 1 week before the experiments and were given free access to standard laboratory animal diet and water ad libitum.

\section{Treatment regimen}

To study the effect of prophylactic treatment with chrysin on CDDP-induced oxidative stress and apoptotic responses in the jejunum, thirty male Wistar rats were randomly allocated to five groups of six rats each. The rats of Group I (control 

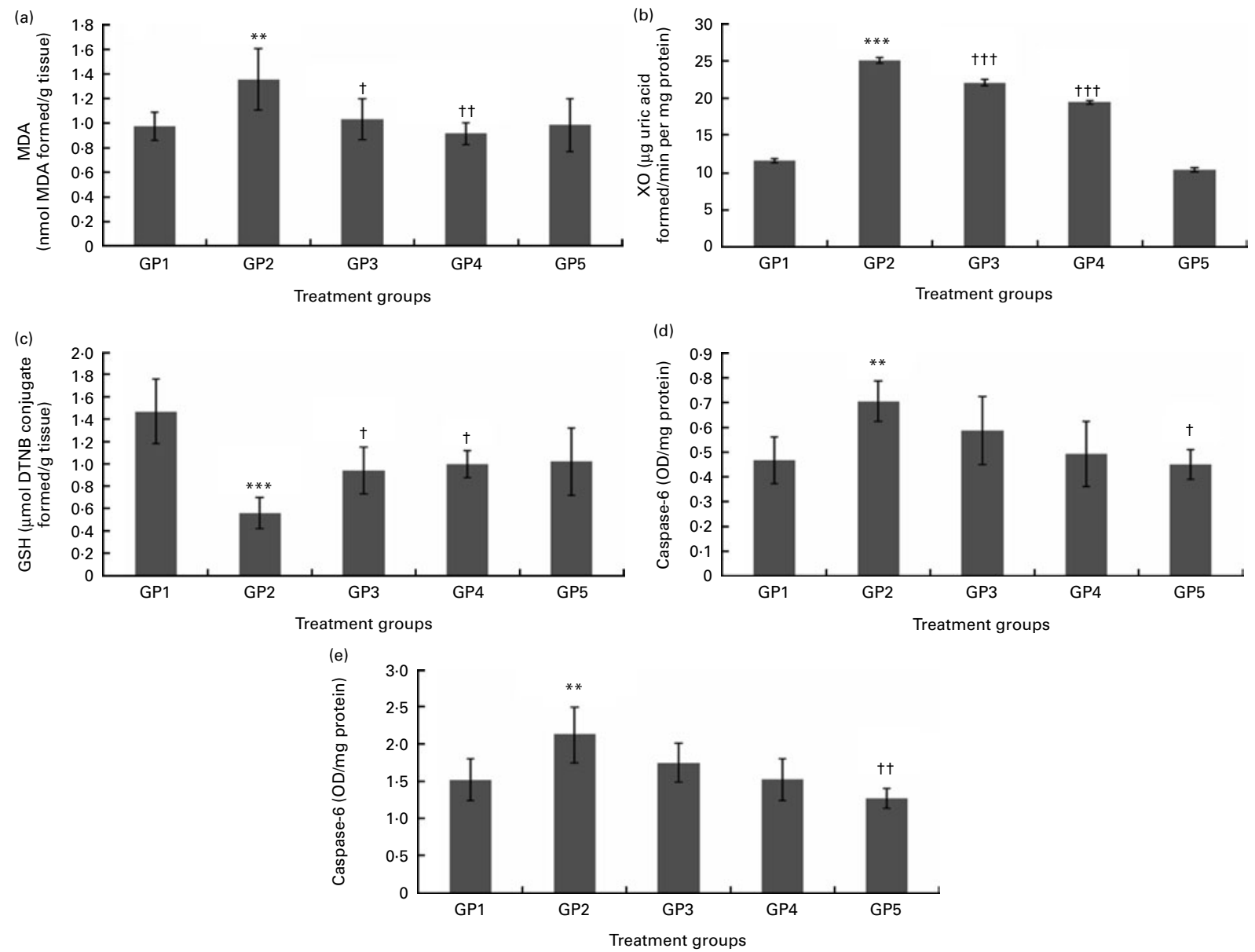

Fig. 2. Effects of chrysin and cisplatin (CDDP) on different parameters: Group I (GP1) - vehicle-treated control group (maize oil - $5 \mathrm{ml} / \mathrm{kg}$ body weight (b.wt.)), Group II (GP2) - CDDP-treated group (7.5 mg/kg b.wt.), Group III (GP3) - dose 1 of chrysin (25 mg/kg b.wt.) + CDDP (7.5 mg/kg b.wt.), Group IV (GP4) - dose 2 of chrysin ( $50 \mathrm{mg} / \mathrm{kg}$ b.wt.) + CDDP (7.5 mg/kg b.wt.), Group 5 (GP5) - only dose 2 of chrysin $(50 \mathrm{mg} / \mathrm{kg}$ b.wt.). (a) Effect of prophylactic treatment of chrysin against CDDP-induced lipid peroxidation (malondialdehyde (MDA) level) in jejunum of Wistar rats. Values are means and standard deviations represented by vertical bars $(n 6)$ and measured as nmol MDA formed/g tissue. MDA level was significantly increased $\left({ }^{\star *} P<0.01\right)$ in the CDDP-treated group (GP2) as compared to GP1. Pretreatment with chrysin significantly attenuated the level of MDA in GP3 $(\dagger P<0.05)$ and GP4 $(\dagger \dagger P<0.01)$ as compared to GP2. There was no significant difference between GP5 and GP1. (b) Effect of chrysin pretreatment and CDDP on xanthine oxidase (XO) activity. Values are means and standard deviations represented by vertical bars $(n 6)$ and measured as $\mu \mathrm{g}$ uric acid formed/min per mg protein. XO activity was significantly increased $\left(^{* \star *} P<0.001\right)$ in the CDDP-treated group (GP2) as compared to GP1. Pretreatment with chrysin significantly attenuated the activity of XO in GP3 ( $\dagger+\dagger P<0.001)$ and GP4 ( $\dagger+\dagger P<0.001)$ as compared to GP2. However, there was no significant difference between GP5 and GP1. (c) Effect of prophylactic treatment of chrysin against CDDP-induced depletion of reduced glutathione (GSH). Values are means and standard deviations represented by vertical bars $(n 6)$ and measured as $\mu$ mol 5,5'-dithio-bis-(2-nitrobenzoic acid; DTNB) conjugate formed/g tissue. GSH content was significantly decreased ( ${ }^{\star \star \star} P<0.001$ ) in CDDP-treated group (GP2) as compared to GP1. Pretreatment with chrysin significantly prevented the depletion of GSH level in GP3 $(\dagger P<0.05)$ and GP4 $(\dagger P<0.05)$ as compared to GP2. However, there was no significant difference between GP5 and GP1. (d) Effects of chrysin pretreatment and CDDP on the caspase- 6 activity. Values are means and standard deviations represented by vertical bars $(n 6)$ and measured as optical density $(\mathrm{OD}) / \mathrm{mg}$ protein. Caspase- 6 activity was significantly increased $\left({ }^{* *} P<0 \cdot 01\right)$ in the CDDP-treated group (GP2) as compared to GP1. Pretreatment with higher dose of chrysin $(50 \mathrm{mg} / \mathrm{kg}$ b.wt.) significantly attenuated the activity of caspase-6 in GP4 (†P<0.05) as compared to GP2. However, there was no significant difference between GP5 and GP1. (e) Effects of chrysin pretreatment and CDDP on the caspase-3 activity. Values are means and standard deviations represented by vertical bars $(n 6)$ and measured as OD/mg protein. Caspase-3 activity was significantly increased $\left({ }^{* *} P<0.01\right)$ in the CDDP-treated group (GP2) as compared to GP1. Pretreatment with higher dose of chrysin ( $50 \mathrm{mg} / \mathrm{kg}$ b.wt.) significantly attenuated the activity of caspase-3 in GP4 ( $\dagger+P<0.01)$ as compared to GP2. However, there was no significant difference between GP5 and GP1.

group) received maize oil orally at the dose of $5 \mathrm{ml} / \mathrm{kg}$ body weight (b.wt.) once daily for $14 \mathrm{~d}$, which was used as a vehicle for chrysin. Group III received chrysin orally at the dose of $25 \mathrm{mg} / \mathrm{kg}$ b.wt. once daily for 14 consecutive days. Groups IV and $\mathrm{V}$ received chrysin at the dose of $50 \mathrm{mg} / \mathrm{kg} \mathrm{b.wt}$. once daily for $14 \mathrm{~d}$. Groups II, III and IV were given a single injection of CDDP at the dose of $7.5 \mathrm{mg} / \mathrm{kg}$ b.wt., intraperitonially on day 14 after $1 \mathrm{~h}$ of the last treatment with chrysin. All the rats were anaesthetised with mild anaesthesia and killed by cervical dislocation after $24 \mathrm{~h}$ of the CDDP injection (Fig. 1).

\section{Post-mitochondrial supernatant preparation and estimation of different parameters}

Jejunums were removed quickly, cleaned free of irrelevant material and immediately perfused with ice-cold saline $(0 \cdot 85 \% \mathrm{NaCl})$. The jejunums $(10 \% \mathrm{w} / \mathrm{v})$ were homogenised in chilled phosphate buffer $(0 \cdot 1 \mathrm{M}, \mathrm{pH} 7 \cdot 4)$ using a Potter Elvehjen homogeniser. The homogenate was filtered through muslin cloth, and centrifuged at $3000 \mathrm{rpm}$ for $10 \mathrm{~min}$ at $4^{\circ} \mathrm{C}$ in a Remi Cooling Centrifuge (C-24 DL) to separate the nuclear 
debris. The aliquot so obtained was centrifuged at $12000 \mathrm{rpm}$ for $20 \mathrm{~min}$ at $4^{\circ} \mathrm{C}$ to obtain post-mitochondrial supernatant (PMS), which was used as a source of various enzymes.

\section{Measurement of lipid peroxidation}

The assay for membrane lipid peroxidation (LPO) was done by the method of Wright et al. ${ }^{(28)}$ with some modifications. The reaction mixture in a total volume of $3.0 \mathrm{ml}$ contained $1.0 \mathrm{ml}$ tissue homogenate, $1.0 \mathrm{ml}$ of TCA $(10 \%)$ and $1.0 \mathrm{ml}$ thiobarbituric acid (0.67\%). All the test tubes were placed in a boiling-water bath for a period of $45 \mathrm{~min}$. The tubes were then shifted to an ice-bath and centrifuged at $2500 \mathrm{~g}$ for $10 \mathrm{~min}$. The amount of malondialdehyde (MDA) formed in each of the samples was assessed by measuring the optical density of the supernatant at $532 \mathrm{~nm}$. The results were expressed as the nmol MDA formed/g tissue by using a molar extinction coefficient of $1.56 \times 10^{5} / \mathrm{M}$ per $\mathrm{cm}$.

\section{Measurement of xanthine oxidase activity}

The activity of xanthine oxidase (XO) was assayed by the method of Stirpe \& Della Corte ${ }^{(29)}$. The reaction mixture consisted of $0.2 \mathrm{ml}$ PMS which was incubated for $5 \mathrm{~min}$ at $37^{\circ} \mathrm{C}$ with $0.8 \mathrm{ml}$ phosphate buffer $(0.1 \mathrm{M}, \mathrm{pH} 7 \cdot 4)$. The reaction was started by adding $0.1 \mathrm{ml}$ xanthine $(9 \mathrm{~mm})$ and kept at $37^{\circ} \mathrm{C}$ for $20 \mathrm{~min}$. The reaction was terminated by the addition of $0.5 \mathrm{ml}$ ice-cold perchloric acid $(10 \%(\mathrm{v} / \mathrm{v}))$. After $10 \mathrm{~min}$, $2.4 \mathrm{ml}$ of distilled water were added and centrifuged at $4000 \mathrm{rpm}$ for $10 \mathrm{~min}$ and $\mu \mathrm{g}$ uric acid formed $/ \mathrm{min}$ per $\mathrm{mg}$ protein was recorded at $290 \mathrm{~nm}$.

\section{Measurement of reduced glutathione level}

The GSH content in jejunum was determined by the method of Jollow et al. $^{(30)}$ in which $1.0 \mathrm{ml}$ of PMS fraction (10\%) was mixed with $1.0 \mathrm{ml}$ of sulphosalicylic acid (4\%). The samples were incubated at $4^{\circ} \mathrm{C}$ for at least $1 \mathrm{~h}$ and then subjected to centrifugation at $1200 \mathrm{~g}$ for $15 \mathrm{~min}$ at $4^{\circ} \mathrm{C}$. The assay mixture contained $0.4 \mathrm{ml}$ filtered aliquot, $2.2 \mathrm{ml}$ phosphate buffer $(0.1 \mathrm{M}$,

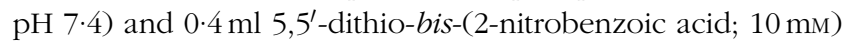
in a total volume of $3.0 \mathrm{ml}$. The yellow colour developed was read immediately at $412 \mathrm{~nm}$ on a spectrophotometer (Milton Roy Model-21 D). The GSH content was calculated as $\mu \mathrm{mol}$ 5,5'-dithio-bis-(2-nitrobenzoic acid) conjugate formed/g tissue using a molar extinction coefficient of $13.6 \times 10^{3} / \mathrm{m}$ per $\mathrm{cm}$.

\section{Measurement of glutathione peroxidase activity}

The glutathione peroxidase (GPx) activity was calculated by the method of Mohandas et al. ${ }^{(31)}$. A total of $2 \mathrm{ml}$ volume consisted of $0.1 \mathrm{ml}$ EDTA ( $1 \mathrm{~mm}), 0.1 \mathrm{ml}$ sodium azide $(1 \mathrm{~mm}), 1.44 \mathrm{ml}$ phosphate buffer (0.1 M, pH 7.4), 0.05 ml GR (1 IU/ml), 0.05 ml GSH (1 mM), $0.1 \mathrm{ml} \mathrm{NADPH}(0.2 \mathrm{~mm})$ and $0.01 \mathrm{ml} \mathrm{H}_{2} \mathrm{O}_{2}$ $(0.25 \mathrm{~mm})$ and $0.1 \mathrm{ml} 10 \%$ PMS. The depletion of NADPH at $340 \mathrm{~nm}$ was recorded at $25^{\circ} \mathrm{C}$. The enzyme activity was calculated as $\mu \mathrm{mol} \mathrm{NADPH}$ oxidised/min per mg protein with the molar extinction coefficient of $6 \cdot 22 \times 10^{3} / \mathrm{M}$ per $\mathrm{cm}$.

\section{Measurement of glutathione-S-transferase activity}

The glutathione-S-transferase (GST) activity was measured by the method of Habig et $a l .{ }^{(32)}$. The reaction mixture consisted of $2.4 \mathrm{ml}$ phosphate buffer $(0.1 \mathrm{M}, \mathrm{pH} 6.5), 0.2 \mathrm{ml} \mathrm{GSH}$ (1.0 mm), $0.2 \mathrm{ml}$ 1-chloro-2,4-dinitrobenzene $(1.0 \mathrm{~mm})$ and $0.2 \mathrm{ml}$ of cytosolic fraction in a total volume of $3.0 \mathrm{ml}$. The changes in absorbance were recorded at $340 \mathrm{~nm}$ and the enzyme activity was calculated as $\mu \mathrm{mol} 1$-chloro-2,4-dinitrobenzene conjugate formed/min per $\mathrm{mg}$ protein using a molar extinction coefficient of $9.6 \times 10^{3} / \mathrm{M}$ per $\mathrm{cm}$.

\section{Measurement of glutathione reductase activity}

The GR activity was measured by the method of Carlberg \& Mannervik ${ }^{(33)}$. The assay system consisted of $1.65 \mathrm{ml}$ phosphate buffer (0.1 M, pH 7.6), 0.1 ml EDTA (0.5 mm), $0.05 \mathrm{ml}$ oxidizsed glutathione $(1 \cdot 0 \mathrm{~mm}), 0 \cdot 1 \mathrm{ml} \mathrm{NADPH}(0 \cdot 1 \mathrm{~mm})$ and $0.1 \mathrm{ml}$ of $10 \%$ PMS in a total volume of $2.0 \mathrm{ml}$. The enzyme activity was assessed at $25^{\circ} \mathrm{C}$ by measuring the disappearance of NADPH at $340 \mathrm{~nm}$ and was calculated as nmol NADPH oxidised/min per mg protein using a molar extinction coefficient of $6.22 \times 10^{3} / \mathrm{M}$ per $\mathrm{cm}$.

\section{Measurement of g/ucose-6-phosphate dehydrogenase activity}

The activity of glucose-6-phosphate dehydrogenase (G6PD) was determined by the method of Zaheer et al. ${ }^{(34)}$. The reaction mixture consisted of $0.3 \mathrm{ml}$ Tris $-\mathrm{HCl}$ buffer $(0.05 \mathrm{M}, \mathrm{pH}$ 7.6), $0 \cdot 1 \mathrm{ml}$ NADP $(0 \cdot 1 \mathrm{~mm}), 0 \cdot 1 \mathrm{ml}$ glucose-6-phosphate (0.8 mm), $0.1 \mathrm{ml} \mathrm{MgCl}_{2}$ ( $8 \mathrm{~mm}$ ), $0.3 \mathrm{ml} \mathrm{PMS} \mathrm{(10 \% )} \mathrm{and} 2 \cdot 1 \mathrm{ml}$ distilled water in a total volume of $3 \mathrm{ml}$. The changes in absorbance were recorded at $340 \mathrm{~nm}$ and the enzyme activity was calculated as nmol NADP reduced/min per $\mathrm{mg}$ protein using a molar extinction coefficient of $6.22 \times 10^{3} / \mathrm{m}$ per $\mathrm{cm}$.

\section{Measurement of superoxide dismutase activity}

The superoxide dismutase (SOD) activity was measured by the method of Marklund \& Marklund ${ }^{(35)}$. The reaction mixture consisted of $2.875 \mathrm{ml}$ Tris- $\mathrm{HCl}$ buffer ( $50 \mathrm{~mm}$, pH 8.5), pyrogallol $(24 \mathrm{~mm}$ in $10 \mathrm{~mm} \mathrm{HCl}$ ) and $100 \mu \mathrm{l}$ PMS in a total volume of $3 \mathrm{ml}$. The enzyme activity was measured at $420 \mathrm{~nm}$ and was expressed as units/mg protein. Here, one unit of enzyme is defined as the enzyme activity that inhibits the auto-oxidation of pyrogallol by $50 \%$.

\section{Measurement of catalase activity}

The catalase (CAT) activity was measured by the method of Claiborne ${ }^{(36)}$. In brief, the assay mixture consisted of $2.0 \mathrm{ml}$ phosphate buffer $(0 \cdot 1 \mathrm{M}, \mathrm{pH} 7 \cdot 4), 0.95 \mathrm{ml} \mathrm{H}_{2} \mathrm{O}_{2}(0 \cdot 019 \mathrm{M})$ and $0.05 \mathrm{ml}$ of PMS $(10 \%)$ in a final volume of $3.0 \mathrm{ml}$. Changes in absorbance were recorded at $240 \mathrm{~nm}$. The CAT activity was calculated in terms of $\mathrm{nmol} \mathrm{H}_{2} \mathrm{O}_{2}$ consumed/min per mg protein. 


\section{Measurement of quinone reductase activity}

The quinone reductase (QR) activity was determined by the method of Benson et al. ${ }^{(37)}$. The $3 \mathrm{ml}$ reaction mixture consisted of $2.13 \mathrm{ml}$ Tris- $\mathrm{HCl}$ buffer ( $25 \mathrm{~mm}, \mathrm{pH} 7 \cdot 4), 0.7 \mathrm{ml}$ bovine serum albumin, $0.1 \mathrm{ml} \mathrm{FAD,} 0.02 \mathrm{ml} \mathrm{NADPH}(0.1 \mathrm{~mm})$ and $50 \mu \mathrm{l}$ PMS $(10 \%)$. The reduction of dichlorophenolindophenol was recorded colorimetrically at $600 \mathrm{~nm}$ and the enzyme activity was calculated as $\mu \mathrm{mol}$ of dichlorophenolindophenol reduced $/ \mathrm{min}$ per $\mathrm{mg}$ protein using a molar extinction coefficient of $2 \cdot 1 \times 10^{4} / \mathrm{M}$ per $\mathrm{cm}$.

\section{Immunohistochemical staining for detection of p53}

Sections of $4 \mu \mathrm{m}$ were cut from formalin-fixed, paraffinembedded tissue blocks and mounted on poly-L-lysinecoated microscopic slides. The paraffinised sections were dewaxed in xylene and rehydrated through graded series of ethanol to water followed by antigen retrieval in sodium citrate buffer ( $10 \mathrm{~mm}, \mathrm{pH} 6 \cdot 0)$. The slides were then allowed to cool for $15 \mathrm{~min}$ and washed three times with Tris-buffered saline (TBS) for 5 min each. The slides were next incubated in $3 \% \mathrm{H}_{2} \mathrm{O}_{2}$ in methanol for $10 \mathrm{~min}$ to reduce the endogenous peroxidase activity and then subjected to power block (UltraVision Plus Detection System; Thermo Scientific) for 10 min to block nonspecific binding. After rinsing the sections in TBS, the slides were incubated overnight at $4^{\circ} \mathrm{C}$ with primary antibody inside a humidified chamber and then were washed in TBS. The sections were incubated with biotinylated goat anti-polyvalent secondary antibody (UltraVision Plus Detection System) for $20 \mathrm{~min}$ and then were rinsed in TBS. The sections were again incubated with streptavidin peroxidase plus (UltraVision Plus Detection System) for $30 \mathrm{~min}$. Following this, the sections were washed in TBS and developed with 3,3'-diaminobenzidine solution (UltraVision Plus Detection System) until they became brown. The sections were next counterstained with Mayer's haematoxylin, mounted by using mounting media and then visualised under a light microscope (Olympus BX51). The primary antibody used was rabbit anti-p53 (dilution 1:100, Santa Cruz).

\section{Measurement of caspase- 6 and -3 activities}

Caspase- 6 and -3 activities were measured with an 'Invitrogen Caspase Colorimetric Protease Assay Sampler Kit' (supplied with VEID (for caspase-6) and DEVD (for caspase-3) substrates) according to the manufacturer's instructions.

\section{Staining for goblet cells analysis}

The jejunal sections of $4 \mu \mathrm{m}$ were cut from formalin-fixed, paraffin-embedded tissue blocks and mounted on poly-L-lysinecoated microscopic slides. The paraffinised sections were dewaxed in xylene and rehydrated through graded series of ethanol to water. The sections were stained with $1 \%$ Alcian blue ( $\mathrm{pH} \mathrm{2.5)}$ in 3\% acetic acid solution for $30 \mathrm{~min}$ and then rinsed for $1 \mathrm{~min}$ in $3 \%$ acetic acid solution to prevent nonspecific staining. The slides were next washed in distilled water and the sections were counterstained with neutral red
( $0.5 \%$ aqueous solution) for $20 \mathrm{~s}$, dehydrated in alcohol and mounted by using mounting media. Following this, the slides were evaluated under the light microscope (Olympus BX51).

\section{Histology}

The jejunum was excised, flushed with saline, cut open longitudinally along the main axis, and then again washed with saline. These jejunal sections were fixed in $10 \%$ buffered formalin for at least $24 \mathrm{~h}$ and after fixation, the specimens were dehydrated in ascending grades of ethanol, cleared in benzene, and embedded in paraffin wax. Blocks were made and $5 \mu \mathrm{m}$-thick sections were cut from the jejunum. The paraffin-embedded jejunal tissue sections were deparaffinised using xylene and ethanol. The slides were washed with PBS and permeabilised with permeabilisation solution ( $0 \cdot 1 \mathrm{M}$-citrate, $0 \cdot 1 \%$ Triton $\mathrm{X}-100)$. These sections were stained with haematoxylin and eosin and were observed under a light microscope at $40 \times$ magnification to investigate the histoarchitecture of jejunal mucosa.

\section{Measurement of protein}

The protein concentration in all samples was determined by the method of Lowry et al. ${ }^{(38)}$ using bovine serum albumin as the standard.

\section{Statistical analysis}

The data from individual groups were presented as the means and standard deviations. Differences between groups were analysed using ANOVA followed by Dunnett's multiple comparisons test and the minimum criterion for statistical significance was set at $P<0.05$ for all comparisons.

\section{Results}

\section{Effect of prophylactic treatment of chrysin against cisplatin-induced lipid peroxidation}

The level of MDA was significantly enhanced $(P<0 \cdot 01)$ in Group II as compared to Group I. Chrysin pretreatment significantly decreased the level of MDA in Group III $(P<0.05)$ and Group IV $(P<0.01)$, respectively, as compared to Group II. No significant difference was found in the level of MDA between Group I and Group V (Fig. 2(a)).

\section{Effect of chrysin pretreatment and cisplatin on the xanthine oxidase activity in jejunum}

The activity of $\mathrm{XO}$ was significantly increased $(P<0 \cdot 001)$ in Group II as compared to Group I. Chrysin pretreatment significantly decreased the activity of $\mathrm{XO}$ in Group III $(P<0.001)$ and Group IV $(P<0.001)$ as compared to Group II. Group V exhibited no significant change in the activity of XO as compared to Group I (Fig. 2(b)). 
Table 1. Effects of chrysin and cisplatin (CDDP) on the activities of glutathione peroxidase (GPx), glutathione-S-transferase (GST) and glutathione reductase (GR) in rat jejunum

(Mean values and standard deviations)

\begin{tabular}{|c|c|c|c|c|c|c|c|c|}
\hline \multirow[b]{2}{*}{ Treatment groups } & \multicolumn{2}{|c|}{ GPx } & \multicolumn{2}{|c|}{ GST } & \multicolumn{2}{|c|}{ GR } & \multicolumn{2}{|c|}{ G6PD } \\
\hline & Mean & SD & Mean & SD & Mean & SD & Mean & SD \\
\hline I (vehicle-treated control) & 1.89 & 0.14 & 1.46 & 0.23 & 793.96 & $115 \cdot 17$ & 208.44 & $30 \cdot 69$ \\
\hline II (CDDP only) & $1 \cdot 13^{\star \star *}$ & 0.12 & $0.54^{\star * *}$ & 0.19 & $355 \cdot 2^{\star \star *}$ & $84 \cdot 22$ & $102 \cdot 93^{\star \star \star}$ & 18.88 \\
\hline III (CDDP + chrysin D1) & 1.22 & 0.15 & $0.94 \dagger$ & 0.14 & 435.45 & $40 \cdot 07$ & 131.94 & $21 \cdot 24$ \\
\hline IV (CDDP + chrysin D2) & $1.44 \dagger \dagger$ & 0.09 & $1.00 \dagger$ & 0.11 & 676.41††† & 55.66 & $197 \cdot 23+\uparrow \dagger$ & $23 \cdot 36$ \\
\hline $\mathrm{V}$ (chrysin D2 only) & 1.85 & 0.15 & 1.33 & 0.37 & 785.91 & 54.69 & 200.94 & 42.06 \\
\hline
\end{tabular}

G6PD, glucose-6-phosphate dehydrogenase.

*** Mean value was significantly different from that of Group I $(P<0.001)$

Mean value was significantly different from that of Group II: $† P<0.05$, †† $P<0.01$, ††† $P<0.001$.

\section{Effect of prophylactic treatment of chrysin against cisplatin-induced reduced glutathione depletion in the jejunum}

The level of GSH was depleted significantly $(P<0 \cdot 001)$ in the CDDP-treated group (Group II) as compared to the control group (Group I). Chrysin pretreatment showed a significant increase in the level of GSH in Group III $(P<0.05)$ and Group IV $(P<0.05)$ when compared with Group II. No significant difference was found in the level of GSH between Group I and Group V (Fig.2(c)).

\section{Effect of chrysin supplementation and cisplatin on the}

activities of glutathione-dependent enzymes in the

jejunum

CDDP treatment caused a significant decrease in the activities of GPx $(P<0.001)$, GST $(P<0.001)$, GR $(P<0.001)$ and G6PD $(P<0.001)$ in Group II as compared to Group I. Chrysin supplementation at the dose of $25 \mathrm{mg} / \mathrm{kg}$ b.wt. significantly increased the activity of GST only $(P<0.05)$ but not other enzymes in Group III as compared to Group II. But the higher dose of chrysin $(50 \mathrm{mg} / \mathrm{kg}$ b.wt.) significantly attenuated the activities of GPx $(P<0 \cdot 01)$, GST $(P<0.05)$, GR $(P<0.001)$ and G6PD $(P<0.001)$ in Group IV as compared to Group II. However, the activities of these enzymes in Group V did not change significantly as compared to Group I (Table 1).
Effect of chrysin supplementation and cisplatin on the activities of antioxidant enzymes in the jejunum

The activities of CAT, QR and SOD were decreased significantly $(P<0.05, P<0.001$ and $P<0.001$, respectively), in Group II as compared to Group I. Chrysin pretreatment at the dose of $25 \mathrm{mg} / \mathrm{kg}$ b.wt.. significantly augmented the activities of CAT $(P<0.05), \mathrm{QR}(P<0.01)$ and SOD $(P<0.001)$ in Group III as compared to Group II. The higher dose of chrysin $(50 \mathrm{mg} / \mathrm{kg}$ b.wt.) also showed significant increase in the activities of CAT $(P<0.05)$, QR $(P<0.001)$ and SOD $(P<0.001)$ in Group IV as compared to Group II. However, the activities of these enzymes in Group V did not change significantly as compared to Group I (Table 2).

\section{Effect of chrysin pretreatment and cisplatin on the expression of $p 53$ in the jejunum}

The jejunal sections of the CDDP-treated group (Group II) have more p53 immunopositive staining (arrows) as indicated by brown colour as compared to the control group (Group I), while pretreatment with chrysin in Groups III and IV reduced p53 immunostaining as compared to Group II. However, there were no significant differences in the immunostaining in Group V as compared to Group I. For immunohistochemical analyses, brown colour indicates specific immunostaining of p53 and light-blue colour indicates haematoxylin staining. Original magnification, $40 \times$ (Fig. 3).

Table 2. Effects of chrysin and cisplatin (CDDP) on the activities of catalase (CAT), glucose-6phosphate dehydrogenase and quinone reductase (QR) in rat jejunum (Mean values and standard deviations)

\begin{tabular}{|c|c|c|c|c|c|c|}
\hline \multirow[b]{2}{*}{ Treatment groups } & \multicolumn{2}{|c|}{ CAT } & \multicolumn{2}{|c|}{ QR } & \multicolumn{2}{|c|}{ SOD } \\
\hline & Mean & SD & Mean & SD & Mean & SD \\
\hline I (vehicle-treated control) & 240.42 & 39.19 & 3.7 & 0.83 & $23 \cdot 6$ & 0.57 \\
\hline II (CDDP only) & $169 \cdot 73^{\star}$ & $29 \cdot 3$ & $1.06^{\star \star \star}$ & 0.31 & $29 \cdot 87^{\star \star \star}$ & 0.79 \\
\hline III (CDDP + chrysin D1) & $248.89 \dagger$ & $36 \cdot 9$ & $2 \cdot 83+\dagger$ & 1.09 & 26.02††† & 0.61 \\
\hline IV (CDDP + chrysin D2) & $251.93 \dagger$ & $49 \cdot 4$ & $3 \cdot 15+\dagger \dagger$ & 0.58 & $24 \cdot 31+\dagger \dagger$ & 0.72 \\
\hline $\mathrm{V}$ (chrysin D2 only) & 225.45 & 38.94 & 3.67 & 0.8 & $22 \cdot 87$ & 0.68 \\
\hline
\end{tabular}

SOD, superoxide dismutase.

Mean value was significantly different from that of Group I: ${ }^{*} P<0.05,{ }^{* *} p<0.001$.

Mean value was significantly different from that of Group II: $\dagger P<0.05$, $\uparrow \dagger P<0.01$, $\uparrow \dagger \dagger P<0.001$. 

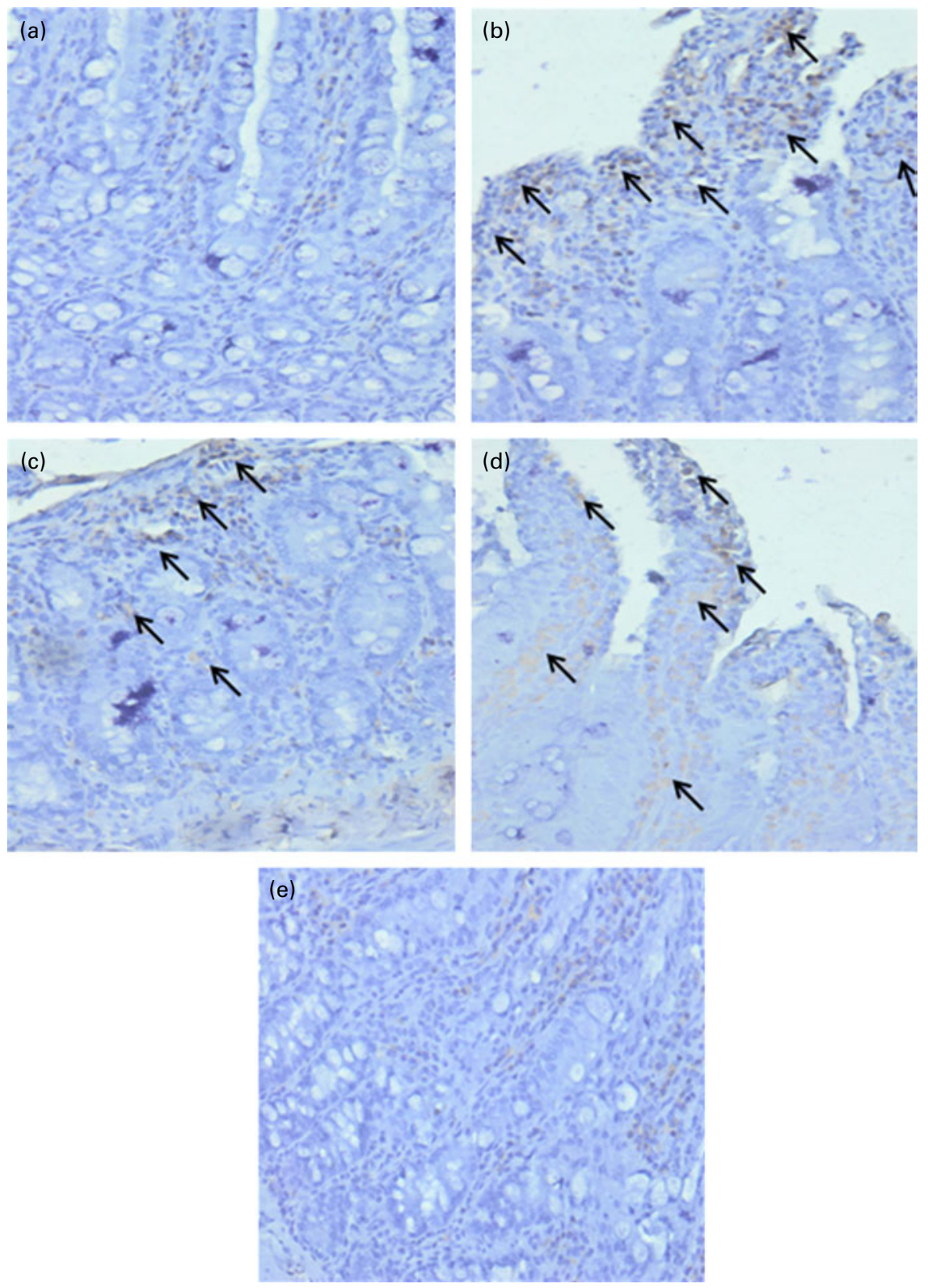

Fig. 3. Effect of chrysin pretreatment on cisplatin (CDDP)-induced p53 expression. Photomicrographs of jejunal sections depicting (a) vehicle-treated control group (Group I), (b) CDDP-treated group (7.5 mg/kg body weight (b.wt.); Group II), (c) dose 1 of chrysin ( $25 \mathrm{mg} / \mathrm{kg}$ b.wt.) + CDDP (Group III), (d) dose 2 of chrysin (50 mg/kg b.wt.) + CDDP (Group IV) and (e) only dose 2 of chrysin $(50 \mathrm{mg} / \mathrm{kg}$ b.wt.; Group V). For immunohistochemical analyses, brown colour indicated specific immunostaining of p53 and light-blue colour indicated nuclear haematoxylin staining. The jejunal section of the CDDP-treated group (Group II) had more p53 immunopositive staining (arrows), as indicated by brown colour, as compared to the control group (Group I), while pretreatment of chrysin in Groups III and IV reduced p53 immunostaining as compared to Group II. However, there was no significant difference in the p53 immunostaining in Group V as compared to Group I. Insets at the right panel show a magnified view ( $40 \times$ magnifications) of the insets showed at the left panel $(10 \times$ magnifications) (a colour version of this figure can be found online at journals.cambridge.org/bjn).

\section{Effect of chrysin pretreatment and cisplatin on the activities of caspase- 6 and -3 in the jejunum}

The CDDP-treated group (Group II) exhibited significant elevation in the activities of caspase-6 $(P<0.01)$ and caspase-3 $(P<0.01)$ as compared to Group I. The higher dose of chrysin $(50 \mathrm{mg} / \mathrm{kg}$ b.wt.) significantly attenuated the activities of caspase-6 $(P<0.05)$ and caspase-3 $(P<0.01)$ in Group IV as compared to Group II. However, there is no significant difference between the activities of caspase- 6 and -3 in Group V as compared to Group I (Fig. 2(d) and (e)).

\section{Effect of chrysin pretreatment against cisplatin-induced goblet cell disintegration in the jejunum}

The jejunal sections of the CDDP-treated group (Group II) showed distorted crypts of Lieberkuhn, the presence of mucus at the apical surfaces of the sections (shown by arrow) and goblet cells disintegration, whereas there was no distortion of crypts of Lieberkuhn, the absence of mucus at the apical surfaces and no disintegration of goblet cells in the control group (Group I). In Groups III and IV, chrysin supplementation at both the doses (50 and $100 \mathrm{mg} / \mathrm{kg}$ b.wt.) 
(a)

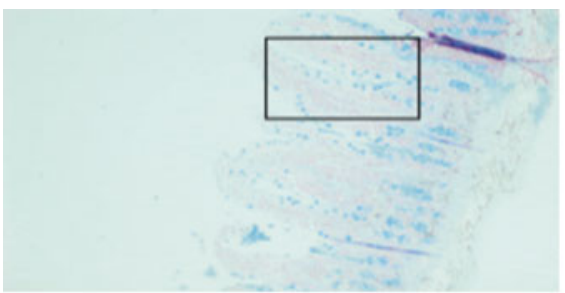

(b)

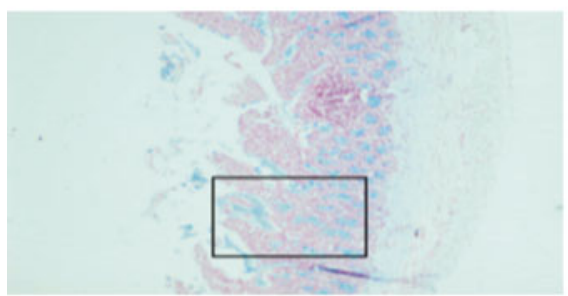

(c)

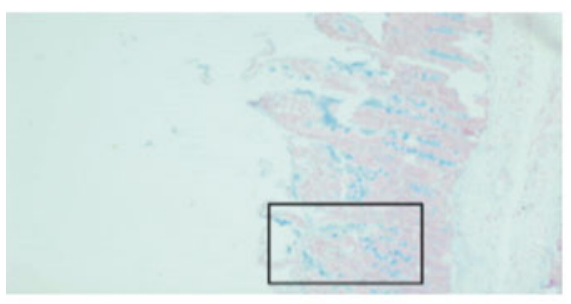

(d)

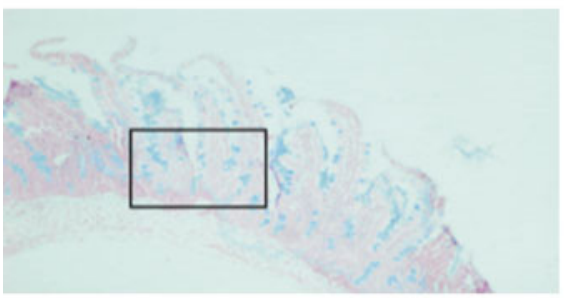

(e)

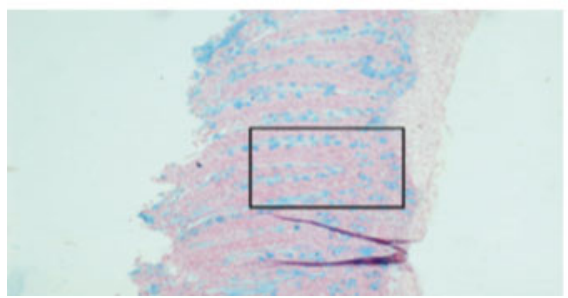

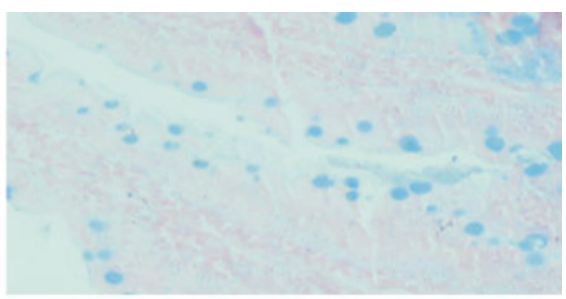
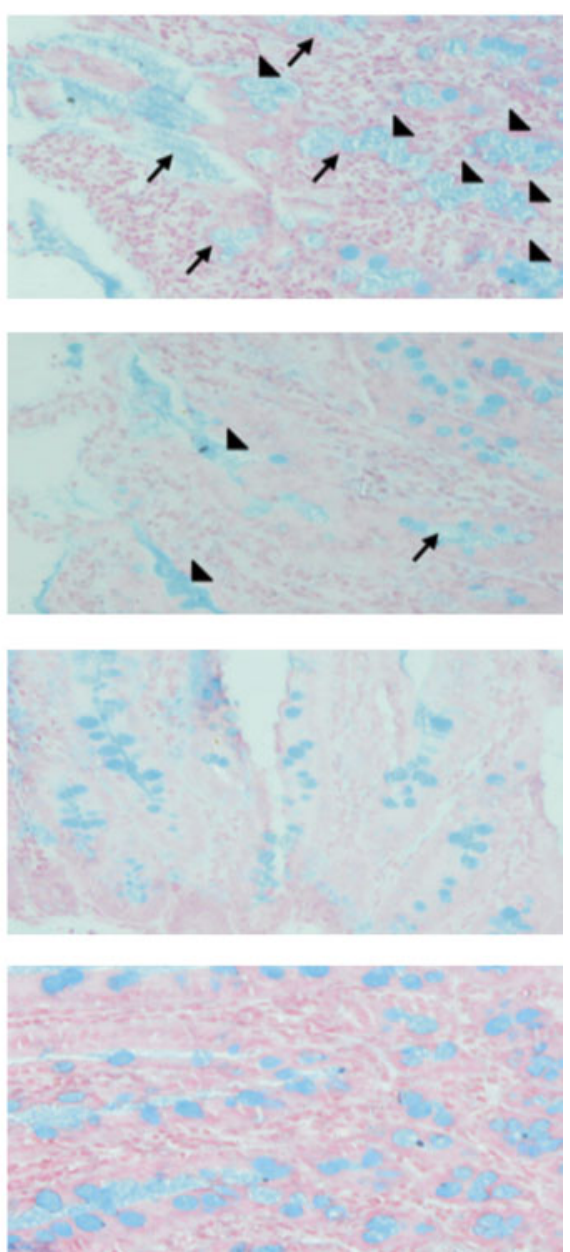

Fig. 4. Effect of chrysin pretreatment on cisplatin (CDDP)-induced goblet cell disintegration. Photomicrographs of jejunal sections depicting (a) vehicle-treated control group (Group I), (b) CDDP-treated group (7.5 mg/kg b.wt.) (Group II), (c) dose 1 of chrysin (25 mg/kg b.wt.) + CDDP (Group III), (d) dose 2 of chrysin $(50 \mathrm{mg} / \mathrm{kg}$ b.wt.) + CDDP (Group IV), (e) only dose 2 of chrysin ( $50 \mathrm{mg} / \mathrm{kg}$ b.wt.) (Group V). The jejunal sections of the CDDP-treated group show distortion of the crypts of Lieberkuhn and goblet cell disintegration. Pretreatment with the higher dose of chrysin $(50 \mathrm{mg} / \mathrm{kg}$ b.wt.) gave more protection than the lower dose $(25 \mathrm{mg} / \mathrm{kg}$ b.wt.) in Group IV as compared to Group II. However, there is no significant difference between Group V and Group I. Insets on the right panel show a

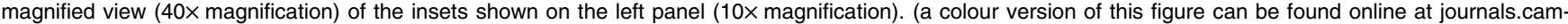
bridge.org/bjn)

showed protection against CDDP-induced distorted crypts of Lieberkuhn, the presence of mucus at the apical surfaces of the sections and goblet cells disintegration as compared to Group II (Fig. 4).

\section{Effects of chrysin pretreatment and cisplatin on histology of the jejunum}

The haematoxylin and eosin-stained sections exhibited normal histoarchitecture with mild inflammatory cells infiltration in the control group (Group I), while the CDDP-treated groups showed distorted mucosal glandular architecture, villous atrophy, crypt ablation with intense inflammatory cell infiltration in the mucosal and submucosal layers. In Groups III and IV, chrysin significantly attenuated the CDDP-induced histopathological changes at both the doses (50 and $100 \mathrm{mg} /$ $\mathrm{kg}$ b.wt.). There is no significant difference in the histological changes in Group V as compared to Group I (Fig. 5).

\section{Discussion}

In the present study, we have observed that pretreatment with chrysin showed protection against CDDP-induced jejunal toxicity. CDDP-induced diarrhoea and apoptosis in the 
(a)

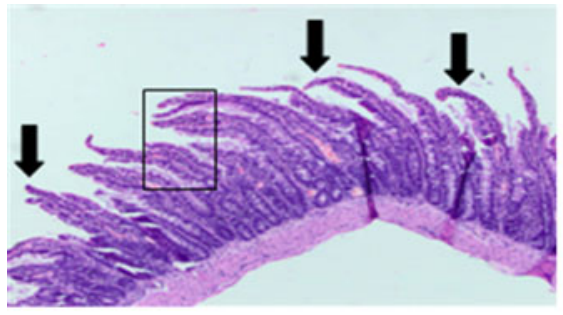

(b)

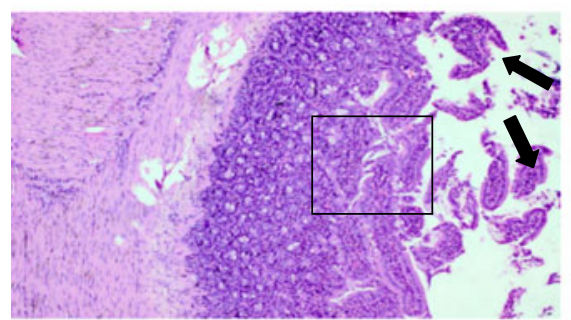

(c)

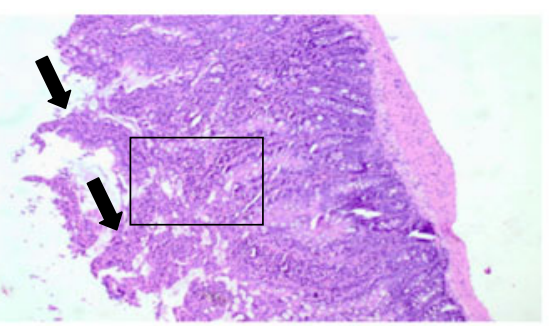

(d)

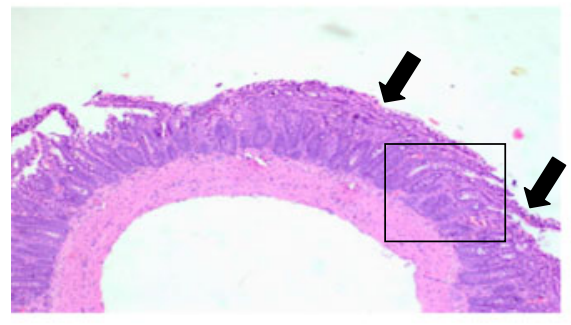

(e)

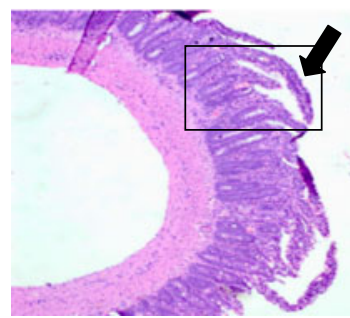

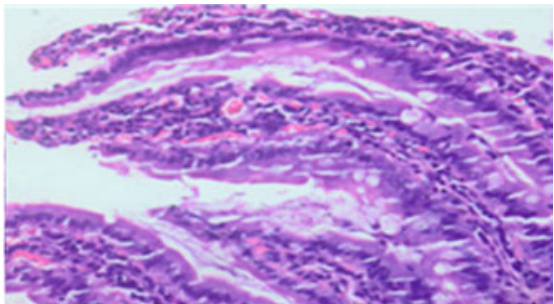
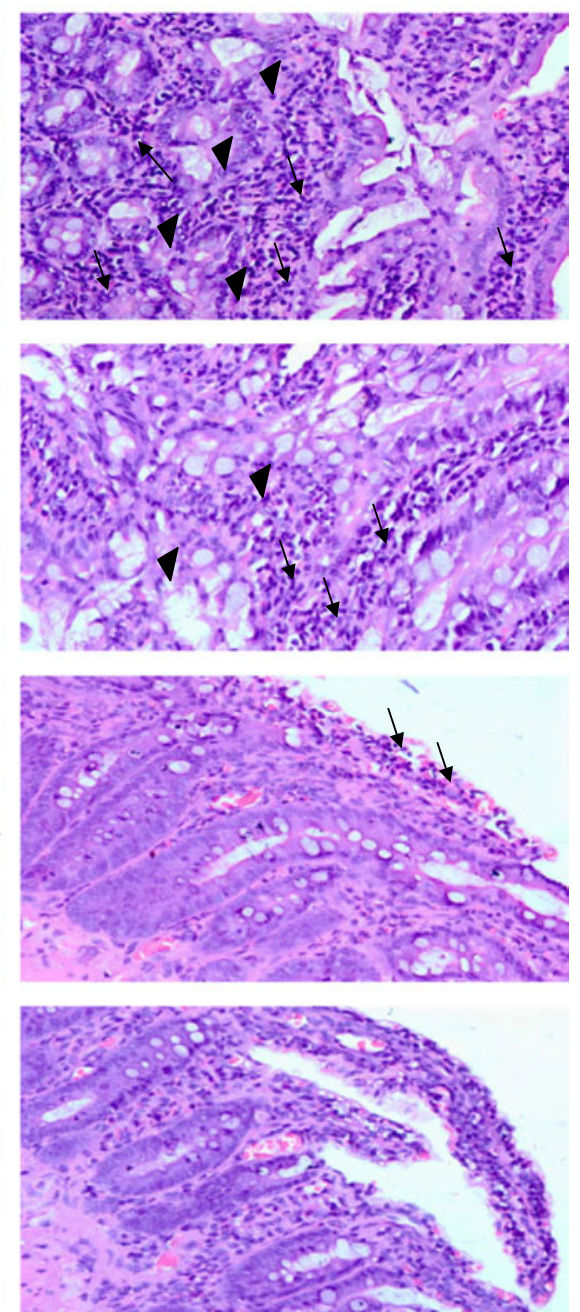

Fig. 5. Effects of chrysin and cisplatin (CDDP) on the histoarchitecture of the jejunum. Photomicrographs of jejunal sections depicting (a) vehicle-treated control group (Group I), (b) CDDP-treated group (7.5 mg/kg body weight (b.wt.); Group II), (c) dose 1 of chrysin (25 mg/kg b.wt.) + CDDP (Group III), (d) dose 2 of chrysin (50 mg/kg b.wt.) + CDDP (Group IV) and (e) only dose 2 of chrysin (50 mg/kg b.wt.; Group V). The haematoxylin and eosin-stained sections exhibited normal histoarchitecture with mild inflammatory cells infiltration in the control group (Group I), while the CDDP-treated group showed distorted mucosal glandular architecture (shown by arrow heads), villous atrophy (shown by bold arrows), and crypt ablation with intense inflammatory cells infiltration in the mucosal and submucosal layers (shown by arrows). Pretreatment with the higher dose of chrysin $(50 \mathrm{mg} / \mathrm{kg}$ b.wt.) significantly attenuated the CDDP-induced histopathological changes in Group IV as compared to Group II, while the lower dose of chrysin $(25 \mathrm{mg} / \mathrm{kg} \mathrm{b}$.wt.) showed less protection as compared to the higher dose. There was no significant difference between the histology of Group V and Group I. Insets on the right panel show a magnified view (40 $\times$ magnifications) of the insets showed on the left panel (10 $\times$ magnifications) (a colour version of this figure can be found online at journals.cambridge.org/bjn).

intestinal epithelial cells are the pitfalls of this chemotherapeutic drug ${ }^{(17)}$. The upsurge for the finding of dietary antioxidants that can effectively protect against CDDPinduced gastrointestinal toxicity is gaining much attention. In the present study, we have observed the protective effects of chrysin against CDDP-induced jejunal toxicity. The data of the present study showed that pretreatment with chrysin resulted in the protection against CDDP-induced jejunal toxicity by amelioration of oxidative stress and apoptotic tissue damage.

CDDP results in the generation of ROS, namely the superoxide anion $\left(\mathrm{O}_{2}^{--}\right), \mathrm{H}_{2} \mathrm{O}_{2}$, hydroxyl radical $(\mathrm{OH})$, etc., which are known to induce oxidative stress. $\mathrm{XO}$ is an enzyme that reduces oxygen $\left(\mathrm{O}_{2}\right)$ to the superoxide anion radical $\left(\mathrm{O}_{2}^{-{ }^{-}}\right)$ and consequently produces oxidative stress ${ }^{(39)}$. The present study exhibited that the activity of XO enhanced after CDDP 


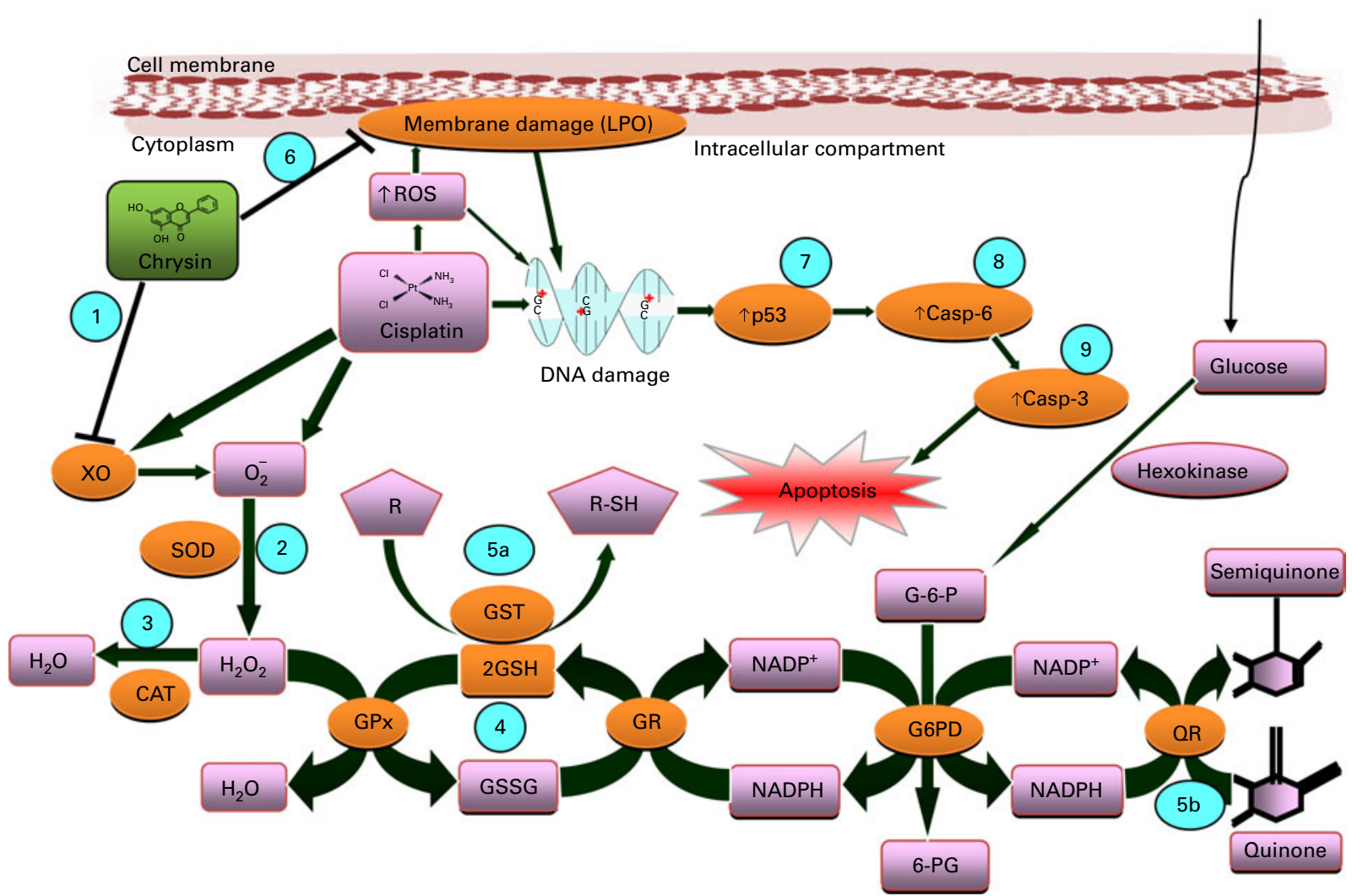

Fig. 6. Targets of action of chrysin against cisplatin (CDDP)-induced debilities, in jejunum of Wistar rats. CDDP causes toxicity via DNA damages and reactive oxygen species (ROS) generation. DNA damage leads to activation of $p 53$ that allows the cells to repair the DNA by blocking the cell cycle. If DNA remains unrepaired, it leads to apoptosis via activation of caspase-6 (Casp-6; initiator caspase) and caspase-3 (Casp-3; executioner caspase). Chrysin pre-treatment shows reduction in xanthine oxidase (XO) activity (1) leading to reduction in ROS formation. Further enhancement in antioxidants like superoxide dismutase (SOD) (2), catalase (CAT) (3) activities and reduced glutathione (GSH) content and related redox cycle enzymes (glutathione reductase (GR), glutathione peroxidise (GPx), and glucose-6-phosphate dehydrogenase (G6PD)) (4) potentiate its role against oxidants-induced damages. Moreover, chrysin pretreatment also increased phase-II metabolising enzyme (glutathione $S$ transferase (GST) and quinone reductase (QR)) activities (5a and $5 \mathrm{~b}$ ). These effects are evident by reduction in lipid peroxidation (LPO) of cellular membranes (6). Chrysin shows the promising role against CDDP-induced apoptotic injuries in jejunums by reducing the levels of p53, Casp-6 and Casp-3 activation (7, 8 and 9 respectively). GSSG, oxidised glutathione; G-6-P, glucose-6-phosphate; 6-PG, 6-phosphogluconate; $\mathrm{O}_{2}^{--}$, superoxide radical; $\mathrm{R}$, xenobiotic; $\mathrm{R}-\mathrm{SH}$, thiol conjugated xenobiotics. (a colour version of this figure can be found online at journals.cambridge.org/bjn)

treatment, while chrysin significantly attenuated its activity; and these ROS may play a key role in the initiation of $\mathrm{LPO}^{(11,12)}$ (Fig. 6).

LPO is a marker of oxidative stress; and remarkable elevation in the level of MDA, a LPO product, was observed after treatment with $\operatorname{CDDP}^{(9,17,19,40)}$. In the present study, it was demonstrated that pretreatment with chrysin significantly attenuated CDDP-induced MDA level.

Besides LPO, the level of GSH also depleted following CDDP treatment. GSH is a low-molecular-weight tripeptide, a cellular antioxidant ${ }^{(41)}$. It protects the peroxidation of lipid membrane by conjugating with the electrophile such as CDDP, which leads to the production of ROS and thus the intracellular level of GSH depleted in GSH-CDDP conjugation reaction $^{(42)}$. This conjugation of GSH via the sulphahydryl (- $\mathrm{SH}$ ) group to electrophile is catalysed by a phase-II detoxifying enzyme, i.e. GST, and thus the activity of GST decreased after CDDP treatment ${ }^{(43)}$. In the present study, it was observed that chrysin supplementation significantly attenuated the GSH level and the activity of GST (Fig. 6).
Moreover, it was observed that the activities of antioxidant enzymes, namely SOD, CAT, GPx, GR and G6PD and a phase-II detoxifying enzyme, namely QR, were diminished in the CDDP-treated group, whereas pretreatment with chrysin significantly attenuated the activities of these antioxidant and phase-II detoxifying enzymes. QR is a phase-II enzyme involved in xenobiotic metabolism that catalyses the twoelectron reduction and thus protects cells against free radicals and ROS generated by the one-electron reductions catalysed by cytochromes P450 and other enzymes ${ }^{(37,44)}$. The diminished activities of antioxidant and phase-II detoxifying enzymes in the CDDP-treated group supported the involvement of oxidative stress in the pathophysiology of CDDP-induced jejunal toxicity (Fig. 6).

CDDP is a DNA-damaging drug and it is also known to generate ROS. These ROS are considered to be the main culprit related to the toxicity of this antineoplastic drug ${ }^{(45)}$ and these ROS also promote the intracellular DNA damage, thus leading to the activation and stabilisation of the genome safeguard, i.e. $\mathrm{p} 53^{(46,47)} \cdot \mathrm{p} 53$ is a key mediator of the DNA damage 
response and is suggested to have an essential role in CDDP toxicity $^{(48)} \cdot \mathrm{p} 53$ is a tumour-suppressor protein and also acts as a transcription factor that regulates the transcription of genes involved in cell cycle, DNA repair and apoptosis ${ }^{(49)}$. Mdm-2 is a co-repressor of $\mathrm{p} 53$ and it maintains the low level of p53 via ubiquitin-mediated proteosomal degradation $^{(50)}$. The present study showed that the CDDP-treated group has more p53 immunopositive staining as compared to the control group, while prophylactic treatment with chrysin significantly attenuated the p53 immunopositive staining. These results further supported the involvement of oxidative DNA damage caused by CDDP-generated ROS (Fig. 6).

p53 can be activated and stabilised in response to several stress signals, namely DNA damage. Upon activation, p53 induces apoptosis, which ultimately leads to the orchestration of caspases and plays a key role in the initiation and execution of cell death ${ }^{(47,51)}$. Caspases are cysteine-dependent enzymes and are activated by oxidative stress ${ }^{(51)}$. Caspase- 6 is considered as an initiator caspase, while caspase- 3 is the main executioner caspase because it can be activated through both intrinsic and extrinsic pathways. Activated caspase- 3 leads to DNA fragmentation and cleavage of specific cellular proteins like PARP, actin and lamins during apoptosis ${ }^{(52)}$. The present study has demonstrated that caspase- 6 and -3 activities significantly up-regulated in the CDDP-treated group and pretreatment with a higher dose of chrysin $(50 \mathrm{mg} / \mathrm{kg}$ b.wt.) significantly attenuated the caspase- 6 and -3 activities.

Goblet cells, the specialised exocrine cells of intestinal crypts, synthesise and secrete mucins. Mucins are high-molecular-weight, highly glycosylated proteins which form a protective layer in the form of gel in the intestinal lumen ${ }^{(53,54)}$. It was observed in our study that chrysin significantly attenuated the CDDP-induced distortion of the crypts of Lieberkuhn and goblet cell disintegration. These results exhibited the protective effects of chrysin against CDDP-induced toxicity.

The aforementioned results further substantiated the histological data which exhibited the protective effects of chrysin against CDDP-induced distorted mucosal glandular architecture, villous atrophy, and crypt ablation with intense inflammatory cell infiltration in the mucosal and submucosal layers.

In conclusion, the results of the present study demonstrate that oxidative stress and apoptosis are closely associated with CDDP-induced toxicity and chrysin shows the protective efficacy against CDDP-induced jejunum toxicity, possibly via attenuating the oxidative stress and apoptotic tissue damage. Chrysin could be used as an adjuvant therapy with CDDP, but the exact mechanism of chrysin is not fully defined yet. Hence, further studies are warranted to elucidate the exact mechanism of action of chrysin.

\section{Acknowledgements}

S.S. is thankful to the University Grants Commission (New Delhi, India), UGC-Special Assistance Programme Departmental Research Support-II (UGC-SAP DRS-II) and a Research Fellowship in Sciences for Meritorious Students (RFSMS) to carry out this work. The contributions of the authors to the present study were as follows: R. K., A. Q. K., W. Q., A. L., M. T.,
F. A. and M. U. R. designed and conducted the experimental work. S. S. designed the experiment and wrote the manuscript. The authors declare that they have no conflicts of interest.

\section{References}

1. Vokes EE, Weichselbaum RR, Mick R, et al. (1992) Favorable long-term survival following induction chemotherapy with cisplatin, fluorouracil, and leucovorin and concomitant chemoradiotherapy for locally advanced head and neck cancer. J Natl Cancer Inst 84, 877-882.

2. Rose PG, Bundy BN, Watkins EB, et al. (1999) Concurrent cisplatin-based radiotherapy and chemotherapy for locally advanced cervical cancer. $N$ Engl J Med 340, 1144-1153.

3. Lebwohl D \& Canetta R (1998) Clinical development of platinum complexes in cancer therapy, an historical perspective and an update. Eur J Cancer 34, 1522-1534.

4. Koc A, Duru M, Ciralik H, et al. (2005) Protective agent, erdosteine, against cisplatin-induced hepatic oxidant injury in rats. Mol Cell Biochem 278, 79-84.

5. Kris M, Gralla R, Clark R, et al. (1988) Control of chemotherapy induced diarrhoea with a synthetic enkephalin BW942C, a randomised trial with placebo in patients receiving cisplatin. J Clin Oncol 6, 663-668.

6. Langerak AD \& Dreisbach LP (2001) Chemotherapy Regimens and Cancer Care. Georgetown, TX: Landes Bioscience.

7. Zicca A, Cafaggi S, Mariggio MA, et al. (2004) Reduction of cisplatin hepatotoxicity by procainamide hydrochloride in rats. Eur J Pharmacol 442, 265-272.

8. Bearcroft CP, Domizio P, Mourad FH, et al. (1999) Cisplatin impairs fluid and electrolyte absorption in rat small intestine, a role for 5-hydroxytryptamine. Gut 44, 174-179.

9. Vijayalakshmi B, Sesikeran B, Udaykumar P, et al. (2006) Chronic low vitamin intake potentiates cisplatin-induced intestinal epithelial cell apoptosis in WNIN rats. World $J$ Gastroenterol 12, 1078-1085.

10. Nakashima-Kamimura N, Mori T, Ohsawa I, et al. (2009) Molecular hydrogen alleviates nephrotoxicity induced by an anti-cancer drug cisplatin without compromising antitumor activity in mice. Cancer Chemother Pharmacol 64 , $753-761$.

11. Aydin B, Unsal M, Sekeroglu ZA, et al. (2011) The antioxidant and antigenotoxic effects of Pycnogenol ${ }^{\circledR}$ on rats treated with cisplatin. Biol Trace Elem Res 142, 638-650.

12. Sun Y (1990) Free radicals, antioxidant enzymes and carcinogenesis. Free Radic Biol Med 8, 583-599.

13. Basu A \& Krishnamurthy S (2010) Cellular responses to cisplatin-induced DNA damage. J Nucleic Acids (epublication ahead of print version 8 August 2010).

14. Sherman SE, Gibson D, Wang AHJ, et al. (1985) X-ray structure of the major adduct of the anticancer drug cisplatin with DNA cis-[Pt (NH3)2 $\{\mathrm{d}(\mathrm{pG} \mathrm{pG})\}]$. Science 230, 412-417.

15. Eastman A (1990) Activation of programmed cell death by anticancer agents, cisplatin as a model system. Cancer Cells 2, 275-280.

16. Atessahin A, Ceribasi AO, Yuce A, et al. (2007) Role of ellagic acid against cisplatin-induced nephrotoxicity and oxidative stress in rats. Basic Clin Pharmacol Toxicol 100, 121-126.

17. Chang B, Nishikawa M, Sato E, et al. (2002) I-Carnitine inhibits cisplatin-induced injury of the kidney and small intestine. Arch Biochem Biophys 405, 55-64.

18. Guerrero-Beltrán CE, Calderón-Oliver M, Tapia E, et al. (2010) Sulforaphane protects against cisplatin-induced nephrotoxicity. Toxicol Lett 192, 278-285. 
19. Kim SH, Hong KO, Hwang JK, et al. (2005) Xanthorrhizol has a potential to attenuate the high dose cisplatin-induced nephrotoxicity in mice. Food Chem Toxicol 43, 117-122.

20. Longo V, Gervasi PG \& Lubrano V (2011) Cisplatin induced toxicity in rat tissues: the protective effect of Lisosan G. Food Chem Toxicol 49, 233-237.

21. Lee CK, Son SH, Park KK, et al. (2008) Licochalcone a inhibits the growth of colon carcinoma and attenuates cisplatininduced toxicity without a loss of chemotherapeutic efficacy in mice. Basic Clin Pharmacol Toxicol 103, 48-54.

22. Karimi G, Ramezani M \& Tahoonian Z (2005) Cisplatin nephrotoxicity and protection by milk thistle extract in rats. Evid Based Complement Alternat Med 2, 383-386.

23. Wang X \& Morris ME (2007) Effects of the flavonoid chrysin on nitrofurantoin pharmacokinetics in rats, potential involvement of ABCG2. Drug Metab Dispos 35, 268-274.

24. Walle $\mathrm{T}$ (2004) Absorption and metabolism of flavonoids. Free Radic Biol Med 36, 829-837.

25. Walle T, Otake Y, Brubaker JA, et al. (2001) Disposition and metabolism of the flavonoid chrysin in normal volunteers. Br J Clin Pharmacol 51, 143-146.

26. Wen X \& Walle T (2006) Methylated flavonoids have greatly improved intestinal absorption and metabolic stability. Drug Metab Dispos 34, 1786-1792.

27. Tsuji PA \& Walle T (2008) Cytotoxic effects of the dietary flavones chrysin and apigenin in a normal trout liver cell line. Chem Biol Interact 171, 37-44.

28. Wright JR, Colby HD \& Miles PR (1981) Cytosolic factors which affect microsomal lipid peroxidation in lung and liver. Arch Biochem Biophys 206, 296-304.

29. Stirpe F \& Della Corte E (1969) The regulation of rat liver xanthine oxidase, conversion in vitro of the enzyme activity from dehydrogenase (type D) to oxidase (type O). J Biol Chem 244, 3855-3863.

30. Jollow DJ, Mitchell JR \& Zampaglione N (1974) Bromobenzene induced liver necrosis, protective role of glutathione and evidence for 3,4-bromobenzene oxide as the hepatotoxic metabolite. Pharmacology 11, 151-169.

31. Mohandas M, Marshall JJ, Duggin GG, et al. (1984) Differential distribution of glutathione and glutathione related enzymes in rabbit kidney. Biochem Pharmacol 33, $1801-1807$.

32. Habig WH, Pabst MJ \& Jakoby WB (1974) Glutathione-Stransferases. The first enzymatic step in mercapturic acid formation. J Biol Chem 249, 7130-7139.

33. Carlberg I \& Mannervik B (1975) Glutathione level in rat brain. J Biol Chem 250, 5475-5480.

34. Zaheer N, Tiwari KK \& Krishnan PS (1965) Exposure and solubilization of hepatic mitochondrial shunt dehydrogenases. Arch Biochem Biophys 109, 646-648.

35. Marklund S \& Marklund G (1974) Involvement of the superoxide anion radical in the autoxidation of pyrogallol and a convenient assay for superoxide dismutase. Eur J Biochem 47, 469-474.

36. Claiborne A (1985) Catalase activity. In CRC Handbook of Methods in Oxygen Radical Research, pp. 283-284 [RA Greenwald, editor]. Boca Raton, RA: CRC.
37. Benson AM, Hunkeler MJ \& Talalay P (1980) Increase of $\mathrm{NAD}(\mathrm{P}) \mathrm{H}$, quinone reductase by dietary antioxidants, possible role in protection against carcinogenesis and toxicity. Proc Natl Acad Sci U S A 77, 5216-5220.

38. Lowry OH, Rosebrough NJ, Farr A, et al. (1951) Protein measurement with the Folin phenol reagent. $J$ Biol Chem 193, 265-275.

39. Heunks LM \& Dekhuijzen PN (2000) Respiratory muscle function and free radicals, from cell to COPD. Thorax $\mathbf{5 5}$, $704-716$.

40. Naghizadeh B, Mansouri SM \& Mashhadian NV (2010) Crocin attenuates cisplatin-induced renal oxidative stress in rats Food Chem Toxicol 48, 2650-2655.

41. Khan R \& Sultana S (2011) Farnesol attenuates 1,2-dimethylhydrazine induced oxidative stress, inflammation and apoptotic responses in the colon of Wistar rats. Chem Biol Interact 192, 193-200

42. Fuertes MA, Alonso C \& Pérez JM (2003) Biochemical modulation of Cisplatin mechanisms of action, enhancement of antitumor activity and circumvention of drug resistance. Chem Rev 103, 645-662.

43. Wang W \& Ballatori N (1998) Endogenous glutathione conjugates, occurrence and biological functions. Pharmacol Rev 50, 335-356.

44. Dinkova-Kostova AT \& Talalay P (2000) Persuasive evidence that quinone reductase type 1 (DT diaphorase) protects cells against the toxicity of electrophiles and reactive forms of oxygen. Free Radic Biol Med 29, 231-240.

45. Kim HJ, Lee JH, Kim SJ, et al. (2010) Roles of NADPH oxidases in cisplatin-induced reactive oxygen species generation and ototoxicity. J Neurosci 30, 3933-3946.

46. Lohrum MAE \& Vousden KH (1999) Regulation and activation of p53 and its family members. Cell Growth Differ 6, 1162-1168

47. Jin S \& Levine AJ (2001) The p53 functional circuit. J Cell Sci 114, 4139-4140.

48. Jiang M \& Dong Z (2008) Regulation and pathological role of p53 in cisplatin nephrotoxicity. J Pharmacol Exp Ther 327, 300-307

49. Riley T, Sontag E, Chen P, et al. (2008) Transcriptional control of human p53-regulated genes. Nat Rev Mol Cell Biol 9, 402-412.

50. Haupt Y, Maya R, Kazaz A, et al. (1997) Mdm2 promotes the rapid degradation of p53. Nature 387, 296-299.

51. Ghavami S, Hashemi M \& Ande SR (2009) Apoptosis and cancer, mutations within caspase genes. J Med Genet $\mathbf{4 6}$, 497-510.

52. Wen J, You KR, Lee SY, et al. (2002) Oxidative stressmediated apoptosis, the anticancer effect of the sesquiterpene lactone parthenolide. J Biol Chem 277, 38954-38964.

53. Specian RD \& Oliver MG (1991) Functional biology of intestinal goblet cells. Am J Physiol 260, C183-C193.

54. Robbe C, Capon C, Coddeville B, et al. (2004) Structural diversity and specific distribution of $O$-glycans in normal human mucins along the intestinal tract. Biochem $J \mathbf{3 8 4}$, $307-316$ 